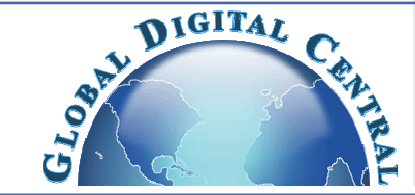

Frontiers in Heat and Mass Transfer

\title{
NUMERICAL INVESTIGATIONS ON COMBUSTION AND EMISSION CHARACTERISTICS IN A DIRECT INJECTION DIESEL ENGINE AT ELEVATED FUEL TEMPERATURES
}

\author{
Manimaran Renganathan, Thundil Karuppa Raj Rajagopal* \\ School of Mechanical \& Building Sciences, VIT University, Vellore-632014, Tamil Nadu, India
}

\begin{abstract}
In this work, fuel spray parameters are studied by varying the fuel temperature. To overcome the tedious experimental task, a 3-D Computational Fluid Dynamics methodology is adopted by injecting fuel at specified temperatures of $313 \mathrm{~K}, 353 \mathrm{~K}$ and $393 \mathrm{~K}$. The validation is accomplished after the optimal spatial and temporal steps of discretization are found out. At a fuel temperature of $313 \mathrm{~K}$, advancing the injection timing from 6 deg bTDC to 20 deg bTDC increases cylinder peak pressure from 79.8 bar to 90.9 bar. Relation between the emission characteristics and spray SMD and temperature is studied.
\end{abstract}

Keywords: Elevated fuel temperature, Direct injection diesel engine, Computational fluid dynamics, Combustion, Emissions

\section{INTRODUCTION}

Since the last decade, the fuels in diesel engine have been substituted or blended with several alternative fuels. However, an attempt to use preheated fuels is rarely reported. It is well known that petroleum fuels when preheated, the surface tension of the fuel droplet decreases. This causes the fuel to atomize in a more fine spray as compared to a fuel when injected at room temperature. However, for alternative or blended fuels, viscosity is reduced by preheating the fuel. Pre-heating the fuel helps in atomization and mixing with the air.

Chhetri and Watts (2012) measured experimentally the surface tensions of diesel and bio-diesel fuels at $473 \mathrm{~K}$ and $7 \mathrm{MPa}$ after the trans-esterification process. They also plotted the variation of surface tension as the temperature is raised from $293 \mathrm{~K}$ to $473 \mathrm{~K}$. The surface tension is found out by creating a pendant drop and analyzing the features of drop and surrounding gas phase. They observed that the surface tension decreases linearly with increase in temperature and pressure. Aleiferis and Romunde found that spray penetration and spray cone angle decreases at higher fuel temperature. They performed Phase Doppler Anemometry (PDA) and LASER Doppler experiments using ethanol and butanol as fuel at an injector body temperature of $393 \mathrm{~K}$ and $453 \mathrm{~K}$. It is intended that flash point is surpassed at an injector body temperature of $453 \mathrm{~K}$ for the fuel considered. At this condition for all the fuels considered, the spray gets evaporated and collapsed, thereby leading to the reduction of spray penetration as compared to $293 \mathrm{~K}$. The cone angle is significantly decreased at $363 \mathrm{~K}$ and $393 \mathrm{~K}$ for n-pentane fuel among the gasoline, iso-octane, butanol and ethanol. They also observed an increase of Reynolds number (Re) and Weber number (We) with increase in temperature of injector body. But Ohnesorge number is found to decrease with fuel injection temperature as given in Eq. (1) (Aleiferis and Romunde, 2012).

$$
\mathrm{Oh}=\mathrm{We}^{0.5} / \mathrm{Re}
$$

The decrease in Sauter Mean Diameter (SMD) is also captured at injector temperature of $393 \mathrm{~K}$ as compared to $293 \mathrm{~K}$. Further reduction in SMD is also observed as the chamber gas (upon which

\footnotetext{
* Corresponding author. Email: tkraj75@gmail.com
}

fuel is injected) pressure is decreased from 1 bar to 0.5 bar. The increase in temperature creates a flash boiling phenomenon inside the injector, which increases the momentum of spray fuel volume leading to the increase in droplet velocities at $393 \mathrm{~K}$ relative to $293 \mathrm{~K}$.

Yilmaz (2012) performed the experiments at preheated air intake temperature of $303 \mathrm{~K}$ and $358 \mathrm{~K}$ for diesel, bio-diesel, blended methanol and ethanol fuels. The increase in intake air temperatures leads to better vaporization of fuel and reduces the $\mathrm{HC} / \mathrm{CO}$ emissions but increases the $\mathrm{NO}_{\mathrm{x}}$ formation and exhaust temperature. Further conclusion is drawn that different ambient temperatures can affect the exhaust gas emissions based on different locations. Myong et al. (2006) carried out the evaporation characteristics for single fuel such as iso-octane, $n$-dodecane and n-hexadecane as these fuels have low, middle and high boiling points respectively. Mie scattered and shadowgraph photographs are obtained for single and multicomponent fuels. The multi-component fuels are obtained in a suitable ratio of combination with the single fuels. The liquid phase length obtained from the experiments remains nearly constant at different injection pressures from 20 bar to 120 bar and injection temperatures of $300 \mathrm{~K}$ but decreases at $368 \mathrm{~K}$. Spray penetration decreases with the increase in ambient gas temperature from $400 \mathrm{~K}$ to $700 \mathrm{~K}$. The effect is more pronounced in single fuel as compared to multi-component fuels considered. Senthil kumar et al. (2005) used animal fat oil as fuel between $303 \mathrm{~K}$ and $343 \mathrm{~K}$ in a direct injection diesel engine. They reported that premixed burning phase is reduced with animal fat oil as compared to diesel. At lower temperature when compared to diesel fuel, $\mathrm{HC} / \mathrm{CO}$ emissions are higher but lower $\mathrm{NO}_{\mathrm{x}}$ emissions with animal fat oil. Preheating the animal fat oil reduces the $\mathrm{HC} / \mathrm{CO}$ emissions but $\mathrm{NO}_{\mathrm{x}}$ emissions increases than diesel. Chen (2008) predicted using simple model that increase in fuel temperature results in increased $\mathrm{CO}, \mathrm{HC}, \mathrm{PM}$, and smoke emissions, and decrease in $\mathrm{NO}_{\mathrm{x}}$. The combustion process, output performance, and emissions of a medium-speed diesel engine were also experimentally investigated. Nwafor (2004) performed experiments and investigated that $\mathrm{CO}$ production with heated fuel is a little higher than the diesel fuel at higher loading conditions. The $\mathrm{CO}$ concentrations in the exhaust were higher for unheated oil operation compared to other fuels. The heated oil showed marginal 
increase in $\mathrm{CO}_{2}$ emissions compared to diesel fuel. The hydrocarbon emissions were significantly reduced when running on plant oils. The fuel consumption was a little worse when running on plant fuel. The ignition delay was longer for unheated plant fuel operation. Bari et al. (2002) focused on finding out the effects of preheating of fuel on the injection system utilising a modified method of friction test, which involves injecting fuel outside the combustion chamber during motoring. Results show that preheating of crude palm oil lowered its viscosity and provided smooth fuel flow up to $373 \mathrm{~K}$. Combustion analyses comparisons between crude palm oil and diesel found that crude palm oil produced a higher peak pressure of $6 \%$, a shorter ignition delay of $2.6{ }^{\circ} \mathrm{CA}$, a lower maximum heat release rate and a longer combustion period. Forson et al. (2004) introduced the mixture of jatropha oil into diesel fuel and found to be effective in reducing the exhaust gas temperatures. The $97.4 \%$ diesel $/ 2.6 \%$ jatropha fuel blend competed favourably with diesel fuel and offers a reasonable, if not even a better, substitute for pure diesel fuel. The test further showed increases in brake thermal efficiency, brake power and reduction of specific fuel consumption for jatropha oil.

Spray atomization and formation of air-fuel mixture are critical phenomena in diesel engine combustion. Ignition delay is influenced by the spray parameters and evaporation chemistry. The ignition delay is also affected by other factors such as injection timing, autoignition temperature of fuel, cetane number, EGR, swirl ratio (SR) and equivalence ratio. Emission parameters like soot and $\mathrm{NO}_{\mathrm{x}}$ are dependent on these variables affected by ignition delay. It has been reported that combustion, pollutant formation and performance are dependent on spray atomization and fuel-air mixing (Heywood, 1988). The spray characteristics affect the initially vaporized fuel fraction. Poor atomization of fuels creates a chance for black smoke and particulate matter. The density and surface tension of diesel fuel decreases with increase in temperature. Higher surface tension and viscosity of diesel fuel decreases the rate of fuel atomization, which in turn increases the spray penetration and SMD of the spray droplets.

Reitz and Diwakar (1986) proposed a spray and atomization model for diesel sprays. The model developed to study internal flow characteristics for a multi-hole fuel injector matches with the available experimental data. Hence this model is used in the present work to study the diesel spray characteristics. Hossainpour and Binesh (2009) explained the physics of different droplet spray models and compared the models for better performance in a direct injection diesel engine. The simulation of combustion is carried out in a CFD code and then validated with experiments. The spray characteristics are predicted better using discrete droplet method. Prasad et al. (2011) performed CFD and experimental studies towards the analysis of injector sac volume and swirl on combustion. The re-entrant piston bowl is able to provide highest turbulent kinetic energy in the cylinder. Sac less injector could result in lower emissions.

From the literature, it is found that many experimental and computational studies are performed to explore the possibilities of improving the combustion efficiency. Further insight into literature also shows the droplet studies on combustion are rarely reported. The study on elevated fuel temperature and related to the spray characteristics are seldom found in literature. This gives the chance to explore into combustion and emission formation at elevated fuel temperature and also study the behavior of droplet parameters considered. Experimental methods on conducting the study of droplet characteristics require expensive LASER instruments and laborious skill. On the other hand, CFD can provide a quick understanding of these phenomena in a very shorter time. Results from computations must be matched with the experiments by adopting suitable discretisation procedures and iterative schemes. Studies are extended to observe the effect of fuel temperature on cylinder variables and droplet parameters. The aim of the present work is to undertake the simulation of spray, combustion and pollutant formation processes and understand the physical phenomena involved at elevated fuel injection temperatures. The computations are carried out in a commercial CFD code (CD-Adapco, 2010), that employs all the models associated with turbulence, spray, combustion and pollutant formation.

\section{NUMERICAL TECHNIQUE}

STAR-CD (CD-Adapco, 2010), $a$ commercial CFD code is used in the present study to explore the combustion and emission formation in a direct injection Diesel engine. The investigation continues with the steps such as preparation of cylinder geometry, meshing, solving and post-processing.

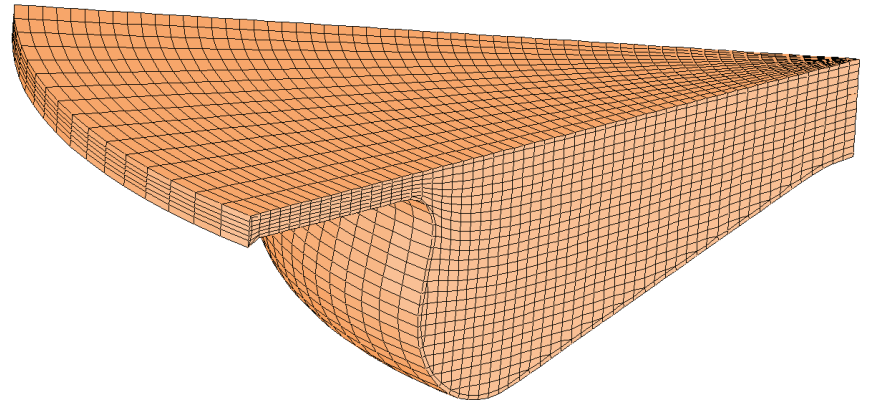

Fig. 1 Computational grid at $720 \mathrm{deg}$ CA (TDC)

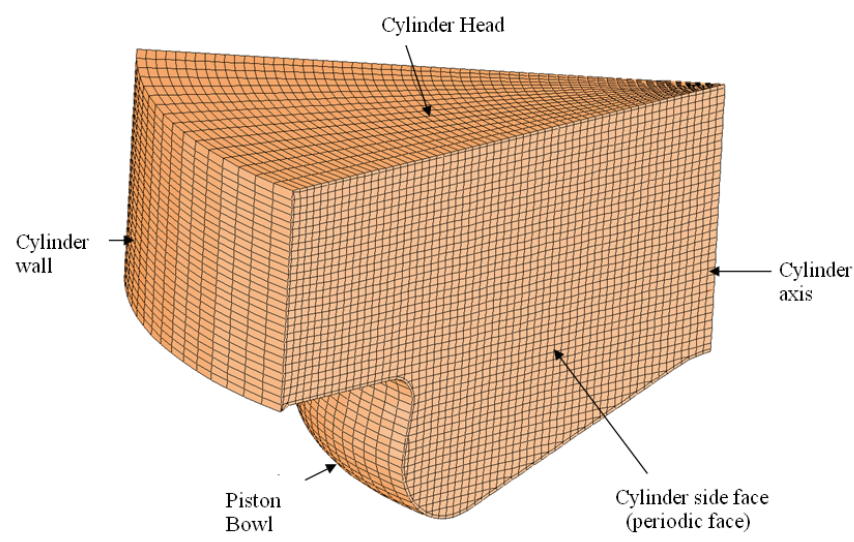

Fig. 2 Computational grid with boundary surfaces at $760{ }^{\circ} \mathrm{CA}(40$ ${ }^{\circ} \mathrm{CA}$ after TDC)

\section{PRE-PROCESSING}

Colin and Benkenida (2004) studied the combustion phenomena in a direct injection diesel engine by considering the re-entrant combustion chamber for a piston bowl. The same combustion chamber geometry is prepared from a CAD package. Once the piston bowl is created, a spline is used to trim the piston wall from a uniform hexahedral mesh. The in-cylinder moving mesh is later obtained for the fluid domain. This is carried out in es-ICE (Expert System Internal Combustion Engine), a grid generation tool. Due to symmetry considerations in the cylinder domain, an extruded geometry of included 45 degrees angle is created and meshed to reduce significant computational time required. Grid at all positions between $\mathrm{BDC}$ and TDC during the $120^{\circ} \mathrm{CA}$ (CA stands for Crank Angle) simulation i.e. between $40^{\circ} \mathrm{CA}$ bTDC and $80^{\circ} \mathrm{CA}$ aTDC, are checked for negative volumes. Computational grid of the moving fluid domain at TDC $\left(720^{\circ} \mathrm{CA}\right)$ and $40^{\circ} \mathrm{CA}$ after TDC $\left(760^{\circ} \mathrm{CA}\right)$ are shown in Figures 1 and 2 respectively. The boundary surfaces consists of moving wall at the bottom, periodic zones at the sides, cylinder wall at the end side, cylinder head wall at the top, axis and the injector. Structured hexahedral mesh and few tetrahedral cells are chosen for meshing the in-cylinder fluid domain and near the fuel injector respectively. Boundary layers are placed at wall regions to 
capture the hydrodynamics boundary layer and thermal boundary layers. Moving grid contains 45000 cells at TDC and the total number of cells required for analysis is verified after carrying out a series of grid independent tests observed in Fig. 3. Increase in number of cells beyond 45000 cells does not further increase the in-cylinder peak pressure and other process variables. Having known the number of cells required, the numerical simulations are grid independent beyond 45000 cells at TDC location. Similar to grid study, time independent study is carried out by varying the time step from $0.1^{\circ} \mathrm{CA}$ to $0.02^{\circ} \mathrm{CA}$ as shown in Fig. 4 in logarithmic scale. Similarly, the in-cylinder averaged peak pressure does not vary even the crank angle step interval is reduced further below $0.025^{\circ} \mathrm{CA}$. The optimum crank angle step interval is fixed at $0.025^{\circ} \mathrm{CA}$ for all simulations in this study.

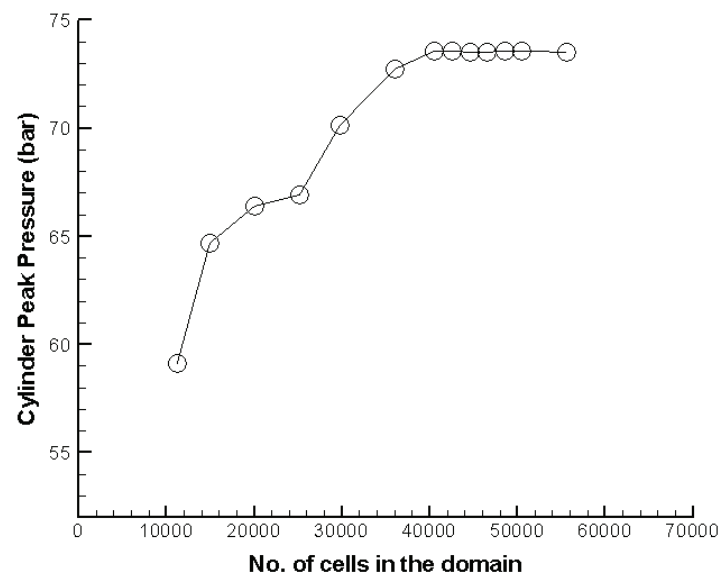

Fig. 3 Variation of peak pressure with grid density

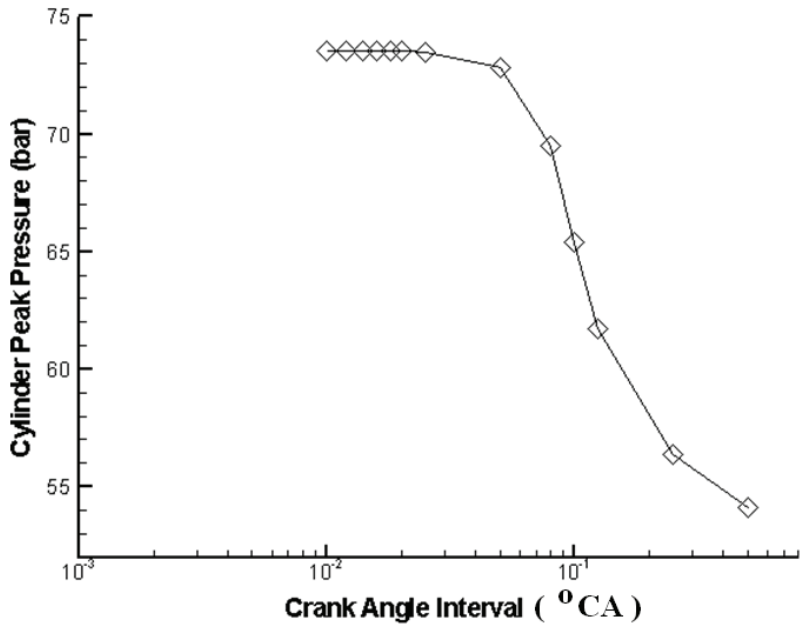

Fig. 4 Variation of peak pressure with crank angle interval

\section{SOLVING METHODOLOGY}

The mesh obtained after carrying out time independent and grid independent study using es-ICE tool, is imported to STAR-CD solver for studying droplet physics, combustion analysis and emission characteristics. The droplet spray phenomenon inside the combustion chamber is taken care by multiphase treatment. The compressed air is considered to be continuous phase which is captured using eulerian approach and the discrete phase is fuel droplet which is captured using lagrangian approach in the CFD code. Turbulent dispersion model is included for the droplet to experience randomly varying velocity field in the cylinder. To detect the collision of fuel droplet parcels for every time step, collision model is also considered. Apart from pressure and shear forces, the droplet parcels also experience the gravitational force field in the domain. In order to capture the droplet trajectory, the number of droplet parcels considered in this work is as high as 50 million and found to be sufficient for capturing the real physics. RNG k- $\varepsilon$ turbulence model (El-Tahry, 1983) is used for modeling the turbulent eulerian flow-field in the cylinder. The 3 zones considered in the combustion model are the unmixed fuel zone, the mixed gases zone and the unmixed zone of air together with EGR The propagation of flame inside the combustion chamber is obtained by solving the flame surface density equation which incorporates the extended coherent flame model (ECFM - 3Z) for the 3 zones. The fuel is injected at $714^{\circ} \mathrm{CA}$ i.e $6^{\circ} \mathrm{CA}$ before TDC. The injection sequence at three crank angles viz. $718^{\circ} \mathrm{CA}$ to $720^{\circ} \mathrm{CA}$ are shown in Fig. 5 (a), (b) and (c) respectively. These figures depict the spray breakup as common in diesel engines due to surface tension and aerodynamic drag force between the fuel and surrounding air under turbulence due to high swirl ratio.

For spray formation, the Reitz and Diwakar (1986) spray droplet model is considered. According to this model, droplet breakup occur in two modes.

(a) Bag Break Up: Droplet breakup occurs due to non-uniform pressure field in the neighborhood of droplet and eventually disintegrates when surface tension forces are overcome. This happens when the Weber number, $\mathrm{W}_{\mathrm{e}}>12$. The lifetime of the droplet in this mode is given as

$$
\tau_{\mathrm{b}}=\left(\pi \rho_{\mathrm{d}}{ }^{1 / 2} \mathrm{D}_{\mathrm{d}}^{3 / 2}\right) /\left(4 \sigma_{\mathrm{d}}{ }^{1 / 2}\right)
$$

(b) Stripping Break Up: Breakup of the liquid droplet occurs by shear due to the large amplitude waves of small or large wavelengths on the droplet surface. Catastrophic break up occurs at high amplitudes. This mode happens if Weber number satisfies the condition,

$$
\mathrm{We} / \mathrm{Re}^{0.5}=0.5
$$

The lifetime of the droplet in this mode is

$$
\tau_{\mathrm{b}}=\left(20 \rho_{\mathrm{d}}{ }^{1 / 2} \mathrm{D}_{\mathrm{d}}\right) /\left(2 \mathrm{u}_{\mathrm{rel}} \rho_{\mathrm{g}}{ }^{1 / 2}\right)
$$

The model accounting for spray impingement with the wall is formulated within the framework of the lagrangian approach to reflect the random nature of the impingement process. A stochastic procedure is adopted to determine the droplet post-impingement quantities. This allows the formation of secondary droplets from primary droplet splash to have a droplet size and droplet velocity distributions. The boundary conditions that are applied to the incylinder fluid domain are listed in Table 1. The STAR-CD code solves the flow field and energy equations by discretizing the fluid domain using finite volume approach under the implicit formulation. Pressure velocity coupling is provided by PISO algorithm (Pressure Implicit by Splitting of Operators) to compute the flow-field and other transport equations. All the conservative equations of mass, momentum and energy in this code are discretised using second order upwind scheme.

Table 1 Boundary Conditions

\begin{tabular}{|c|c|c|}
\hline Boundary & $\begin{array}{c}\text { Momentum boundary } \\
\text { condition }\end{array}$ & $\begin{array}{c}\text { Thermal boundary } \\
\text { condition }\end{array}$ \\
\hline Cylinder head & Wall & $450 \mathrm{~K}$ \\
\hline Cylinder wall & Wall & $400 \mathrm{~K}$ \\
\hline Piston bowl & Moving wall & $450 \mathrm{~K}$ \\
\hline Cylinder side face & Periodic & $450 \mathrm{~K}$ \\
\hline
\end{tabular}

For the simulation of complex mechanisms like turbulent mixing, flame propagation, diffusion combustion and pollutant formations, the ECFM-3Z generalized combustion model (Colin and Benkenida, 2004) is employed in this code. The fresh air is mixed with $31 \%$ of exhaust gas and then introduced into the combustion chamber as per the literature for validation purposes. This modifies 
the fuel/air ratio and lowers the peak temperature so that the chemical reaction rate between nitrogen and any unused oxygen is strongly reduced. Species concentrations involved in combustion reactions can be written as a function of mixture fraction within the presumed probability density function model of combustion. The liquid film model (Angelberger, 1997) accounts for convective transport of conserved quantities within the film and the gas phase. Table 2 lists the various models considered for simulation. The standard pool boiling is used to model liquid film boiling (Rohsenow, 1952), when the wall temperature exceeds the saturation temperature of the liquid as the film starts to boil when the heat flux passes from the wall to the film.

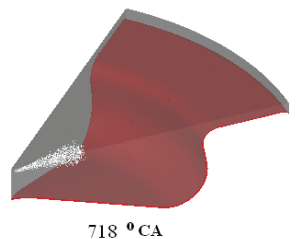

(a)

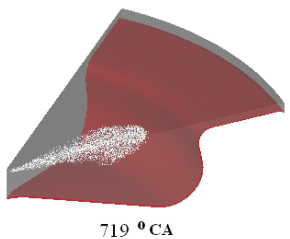

(b)

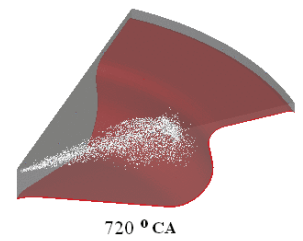

(c)
Fig. 5 Spray visualization: (a) $2^{\circ} \mathrm{CA}$ before TDC, (b) $1^{\circ} \mathrm{CA}$ before TDC and (c) at TDC

Table. 2 Models included in CFD solver

\begin{tabular}{|l|l|}
\hline \multicolumn{1}{|c|}{ Phenomena } & \multicolumn{1}{c|}{ Model } \\
\hline Droplet breakup & Reitz and Diwakar (1986) \\
\hline Turbulence & RNG k- $\varepsilon$ model (El-Tahry, 1983) \\
\hline Combustion & $\begin{array}{l}\text { ECFM-3Z compression (Colin } \\
\text { and Benkenida, 2004) }\end{array}$ \\
\hline Liquid Film & Angelberger et al. (1997) \\
\hline Droplet wall interaction & Bai \& Gosman, (1996) \\
\hline Atomization & Huh and Gosman, (1991) \\
\hline Boiling & Rohsenow (1952) \\
\hline NO $_{x}$ mechanism & Hand et al. (1989) and De Soete, (1975) \\
\hline Soot & Mauss et al., (2006) \\
\hline
\end{tabular}

\section{DROPLET BREAKUP MODEL (Reitz and Diwakar,} 1986)

Droplets from the nozzle enters the combustion chamber at high velocity and gets sheared at the outer periphery. Droplet break-up due to aerodynamic forces occurs in one of the following modes.

1. 'Bag break-up,' in which the non-uniform pressure field around the droplet causes it to expand in the low-pressure wake region and eventually disintegrate when surface tension forces are overcome.

2. 'Stripping break-up,' a process in which liquid is sheared or stripped from the droplet surface.

In each case, theoretical studies have provided a criterion for the onset of break-up and concurrently an estimate of the stable droplet diameter, and the characteristic time scale of the break-up process.

\section{BAI'S SPRAY IMPINGEMENT MODEL (Bai and Gosman, 1996)}

This spray impingement model is formulated within the framework of the lagrangian approach in order to reflect the stochastic nature of the impingement process, a random procedure is adopted to determine some of the droplet post-impingement quantities. This allows secondary droplets resulting from a primary droplet splash to have a distribution of sizes and velocities.

HUH'S ATOMIZATION MODEL (Huh and Gosman, 1991)
Huh's model is based on the gas inertia and the internal turbulence stresses generated in the nozzle. A conceptual picture can be described in two stages:

1. The turbulence generated in the nozzle hole produces initial perturbations on the jet surface when it exits the hole.

2. Once the perturbations have reached a certain level, they grow exponentially via pressure forces induced through interaction with the surrounding gas (surface wave growth), until these perturbations become detached from the jet surface as droplets. The model estimates the initial perturbations from an analysis of the flow through the hole and then uses established wave growth theory, coupled with other hypotheses, to represent the atomisation process.

\section{COMBUSTION \& IGNITION MODELS (Colin and Benkenida, 2004)}

The ECFM-3Z model is a general purpose combustion model capable of simulating the complex mechanisms of turbulent mixing, flame propagation, diffusion combustion and pollutant emission that characterize modern internal combustion engines. ' $3 Z$ ' stands for three zones of mixing, namely the unmixed fuel zone, the mixed gases zone, and unmixed air plus EGR zone. The three zones are too small to be resolved by the mesh and are therefore modeled as subgrid quantities. The mixed zone is the result of turbulent and molecular mixing between gases in the other two zones and is where combustion takes place. The multigrid technique is employed to accelerate the solving the scalar equations of species. The kinetic mechanism involves 1011 reactions and 171 species.

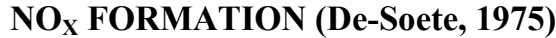

Nitrogen oxides are important air pollutants, mainly produced by combustion devices. The $\mathrm{NO}_{\mathrm{x}}$ concentration is low in most of these devices; therefore, it has little influence on the flow field. Also, the time scale for $\mathrm{NO}_{\mathrm{x}}$ reactions is larger than the time scales for the turbulent mixing process and the combustion of hydrocarbons that control the heat-releasing reactions. Hence, computations of $\mathrm{NO}_{\mathrm{x}}$ can be decoupled from the main reacting flow field predictions. Three different mechanisms have been identified for the formation of nitric oxide during the combustion of hydrocarbons, namely:

\section{Thermal $\mathrm{NO}_{\mathbf{x}}$}

As its name suggests, it is strongly temperature dependent. It is produced by the reaction of atmospheric nitrogen with oxygen at elevated temperatures.

\section{Prompt $\mathrm{NO}_{\mathrm{x}}$}

The exact details of prompt $\mathrm{NO}_{\mathrm{x}}$ formation are still uncertain but are generally believed to involve the reactions between hydrocarbon radicals and atmospheric nitrogen. In certain combustion environments (such as low temperature, fuel-rich conditions and short residence time), prompt $\mathrm{NO}_{x}$ can be produced in significant quantities.

\section{Fuel NO}

This is produced by the reaction of the nitrogenous components present in liquid or solid fossil fuel with oxygen. The fuel nitrogen is a particularly important source of nitrogen oxide emissions for residual fuel oil and coal, which typically contain $0.3-2.0 \%$ nitrogen by weight.

\section{SOOT MODELLING (Mauss et al., 2006)}

The formation and emission of carbonaceous particles is a process that is often observed during the combustion of hydrocarbons. These particulates, called soot, are identified in flames and fires as yellow luminescence. One class of modeling soot formation is based on specifying detailed reaction mechanisms for the gas phase chemistry and the formation, growth and oxidation of soot particles. The first approach, due to Mauss and his colleagues, is based on the laminar flamelet concept in which all scalar quantities are related to the mixture fraction and scalar dissipation rate whereas the species mass 
fractions are unique functions in the mixture fraction-scalar dissipation space, the soot mass fractions are not. The rates of soot formation can, however, be correlated with local conditions in diffusion flames or in partially premixed counter-flow twin flames.

\section{POST-PROCESSING}

The computations are carried out by iterative method until the convergence criterion of 0.00001 is reached for the residual values of the conservation equations of continuity, momentum and energy. Equations governing the turbulence, spray, combustion, $\mathrm{NO}_{\mathrm{x}}$ and soot emissions are also computed at every time step. After a time step is completed, cylinder averaged quantities of interest are obtained from the code for post-processing. Contour information are also obtained at the end of crank angles during the simulation.

\section{VALIDATION}

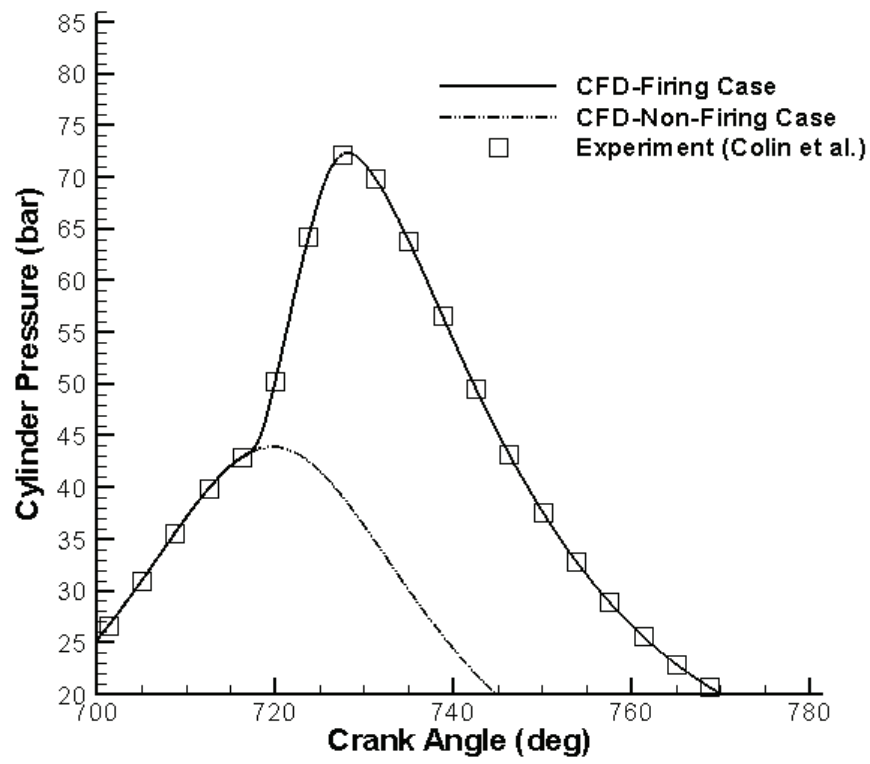

Fig. 6 Comparison of computed and experimental pressures with crank angle

Table 3 Engine specifications

\begin{tabular}{|l|l|}
\hline Bore & $0.085 \mathrm{~m}$ \\
\hline Stroke & $0.088 \mathrm{~m}$ \\
\hline Compression ratio & 18 \\
\hline Connecting Rod Length & $0.145 \mathrm{~m}$ \\
\hline Valves/Cylinder & 4 \\
\hline Engine Speed (N) & $1640 \mathrm{RPM}$ \\
\hline Fuel & $\mathrm{n}$-Dodecane \\
\hline Start of injection (deg bTDC) & 6.0 \\
\hline Injection duration (deg.) & 8.03 \\
\hline Injected mass (g) & 0.0144 \\
\hline F/A equivalence ratio & 0.67 \\
\hline EGR rate (\%) & 31 \\
\hline Swirl ratio (SR) & 2.8 \\
\hline Injector hole diameter & $148 \times 10^{-6} \mathrm{~m}$ \\
\hline Spray angle & $152^{\circ}$ \\
\hline $\begin{array}{l}\text { Intake valve opening } \\
\text { (lift at 0.5 mm) }\end{array}$ & $360^{\circ} \mathrm{CA}(\mathrm{TDC})$ \\
\hline $\begin{array}{l}\text { Intake valve closing } \\
\text { (lift at 0.5 mm) }\end{array}$ & $574{ }^{\circ} \mathrm{CA}$ \\
\hline $\begin{array}{l}\text { Exhaust valve opening } \\
\text { (lift at 0.5 mm) }\end{array}$ & $860^{\circ} \mathrm{CA}$ \\
\hline
\end{tabular}

The specification of engine dimensions, injection timing and combustion parameters are listed in Table 3. The engine geometry is obtained from Colin et al. (Colin and Benkenida, 2004) experimental work. The engine cylinder is modeled for $45^{\circ}$ sector and a series of grid and time independency tests are carried out as shown in Fig. 3 and 4 respectively. Crank angle step interval of $0.025^{\circ} \mathrm{CA}$ and mesh with 45000 cells at TDC position are found from grid and time independence studies. The present simulation work is validated with the experimental pressure data of Colin et al. (Colin and Benkenida, 2012). Figure 6 shows the comparison of the numerically predicted CFD results with the experimental in-cylinder pressure under both firing and motoring conditions. There is a close match between the CFD in-cylinder pressure data and the pressure data from experiments and the maximum deviation of pressure is less than $0.2 \%$. The code, thus employing the flow and combustion physics, captures the timing of maximum pressure rise in a closer range to experiments and hence it can be extended further to study the effect of elevated fuel temperatures on spray characteristics, combustion and pollutant formations.

\section{RESULTS AND DISCUSSION}

Once the validation is accomplished with the experiments, the performance is further increased by tuning the cylinder parameters.

\section{SWIRL RATIO}

It is observed that increasing the swirl ratio could increase the peak pressure and thereby combustion efficiency can be improved. The swirl ratio is found at the end of compression stroke for various piston bowl profiles. Fig. 7 shows the in-cylinder pressure variation with respect to crank angle for different swirl ratio. It is observed that increase in pressure of nearly 6 bar is possible with the proper choice of piston bowl geometry for the combustion chamber. There is a decline in peak pressure at a swirl ratio of 4.5 where as peak pressure increases with swirl ratio from 1.4 to 4.1 . At maximum swirl ratio, turbulent kinetic energy is maximum and leads to the reduction in flame surface density as compared to swirl ratio of 4.1. This affects the combustion phenomena significantly resulting in decrease in heat release. This indirectly affects the peak pressure at maximum swirl ratio of 4.5 .

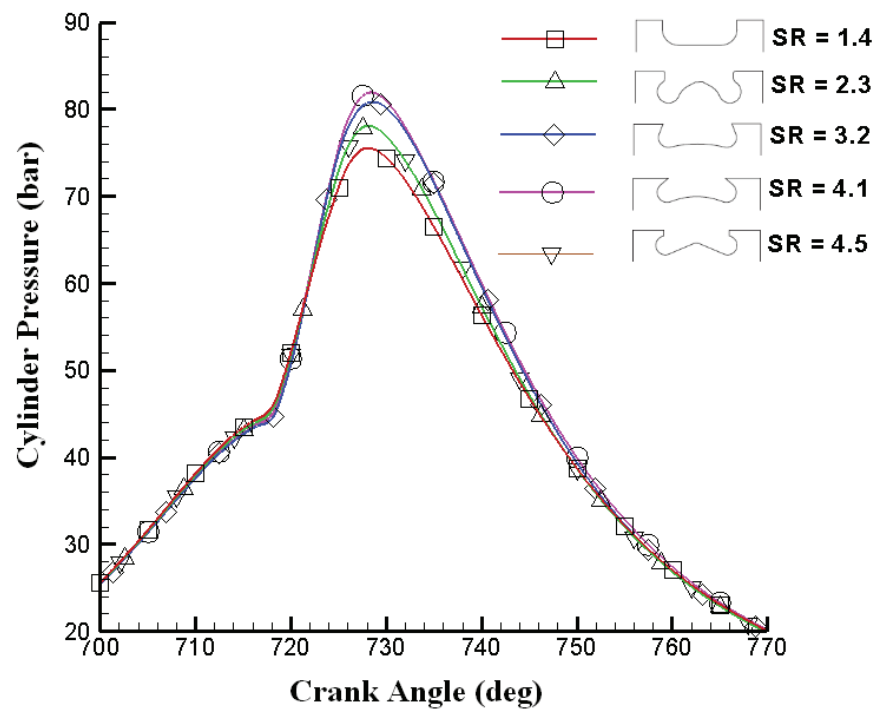

Fig. 7 Influence of swirl ratio on cylinder pressure 


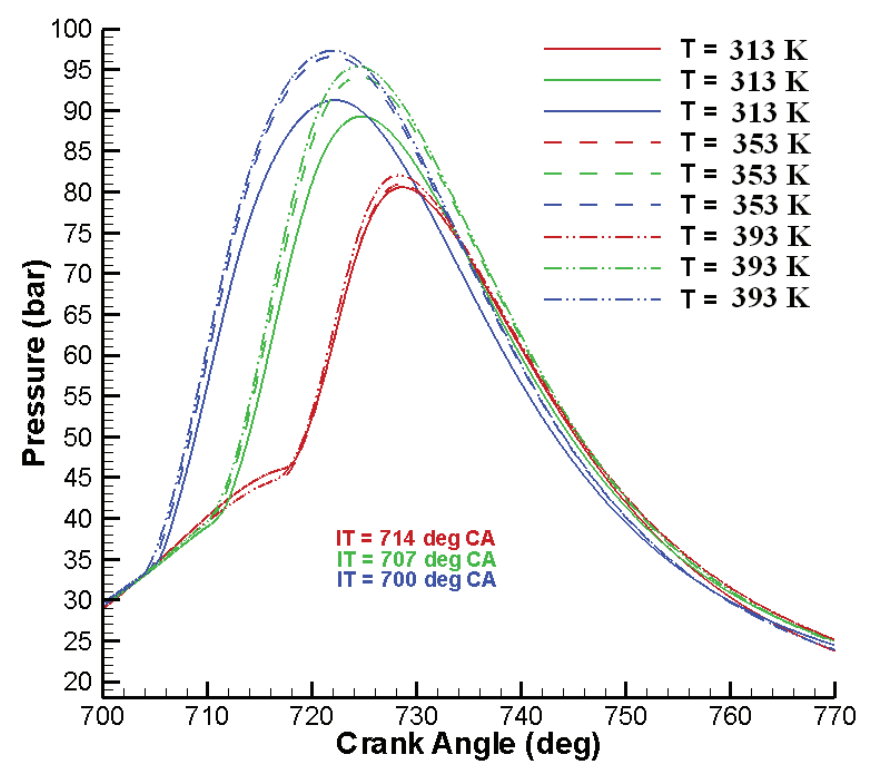

Fig. 8 Variation of cylinder pressure with crank angle for different injection timings an d different fuel injection temperatures

\section{INJECTION TIMING AND ELEVATED FUEL TEMPERATURE}

Similar to swirl ratio (SR), injection timing is also varied and studied here. Injection timing is varied from $6{ }^{\circ} \mathrm{CA}$ bTDC to $27^{\circ} \mathrm{CA}$ bTDC. However, the injection timing at $27{ }^{\circ} \mathrm{CA}$ bTDC is observed to produce lower cylinder pressure as compared to injection timing of 20 ${ }^{\circ} \mathrm{CA}$ bTDC. Hence, injection timing is varied as $6{ }^{\circ} \mathrm{CA}$ bTDC, $13{ }^{\circ} \mathrm{CA}$ bTDC and $20^{\circ} \mathrm{CA}$ bTDC and studied here. Hence swirl ratio of 4.1 is chosen for these studies. Along with the advancement of injection timing (IT), fuel temperature is also varied as $313 \mathrm{~K}, 353 \mathrm{~K}$ and 393 $\mathrm{K}$. This gives a total of 9 simulations to be carried out and compare the combustion and emission parameters.

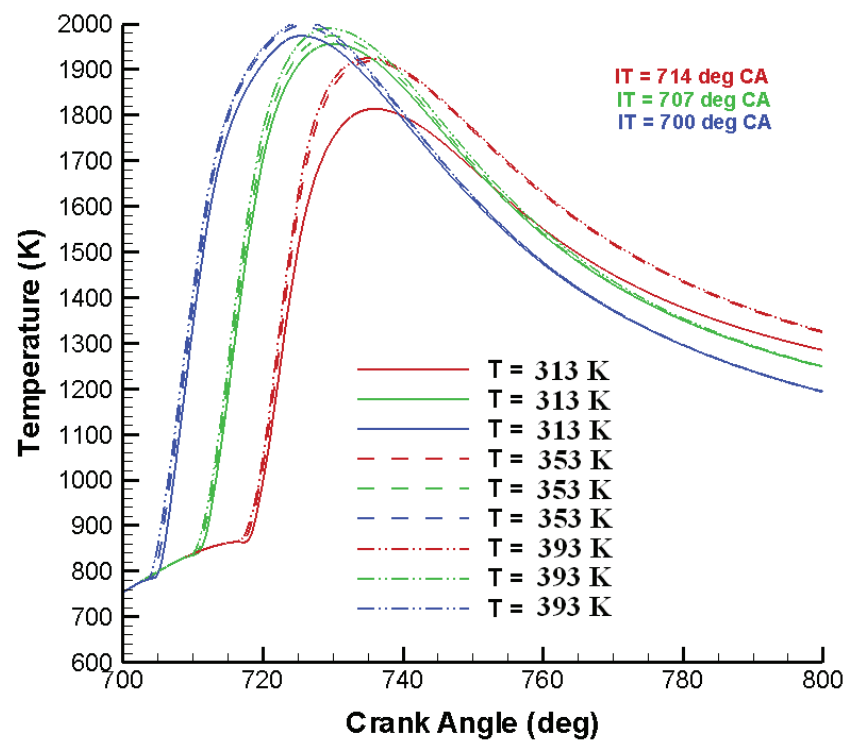

Fig. 9 Variation of cylinder temperature with crank angle for different injection timings and different fuel injection temperatures
Table 4 Ignition delay for various swirl ratio at fuel injection temperature of $313 \mathrm{~K}$ and injection timing of $6{ }^{\circ} \mathrm{CA}$ bTDC

\begin{tabular}{|c|c|}
\hline Swirl Ratio & Ignition Delay $\left({ }^{\mathbf{0}} \mathrm{CA}\right)$ \\
\hline 1.4 & 4.650 \\
\hline 2.3 & 4.225 \\
\hline 3.2 & 3.750 \\
\hline 4.1 & 3.275 \\
\hline 4.5 & 3.125 \\
\hline
\end{tabular}

Variation of the droplet parameters such as droplet mass, droplet SMD, droplet temperature, droplet velocity are also compared among the 9 cases from the simulation. A typical simulation approximately consumes nearly a duration of 12 hours in a Intel Pentium Xeon quadra-core processor with $4 \mathrm{~GB}$ of random access memory and central processing unit clock speed of 3.3 Giga Hertz frequency.

The comparison of cylinder pressure for different injection timings and fuel injection temperatures of $313 \mathrm{~K}, 353 \mathrm{~K}$ and $393 \mathrm{~K}$ is shown in Fig. 8. At a fuel temperature of $313 \mathrm{~K}$, the peak pressures are 79.8 bar, 88.9 bar and 90.9 bar at fuel injection timing of $6{ }^{\circ} \mathrm{CA}$ bTDC, 13 ${ }^{\circ} \mathrm{CA}$ bTDC and $20{ }^{\circ} \mathrm{CA}$ bTDC respectively. When the fuel temperature is increased to $353 \mathrm{~K}$ i.e. safely below its flash point, peak cylinder pressures are increased to 80.1 bar, 94.5 bar and 96.1 bar at fuel injection timing of $6{ }^{\circ} \mathrm{CA}$ bTDC, $13{ }^{\circ} \mathrm{CA}$ bTDC and 20 ${ }^{\circ} \mathrm{CA}$ bTDC respectively. With further increase in temperature of fuel, the increase in peak pressures is very little. The evaporation rate of fuel and spray penetration are enhanced and favorable at fuel temperature of $353 \mathrm{~K}$ as compared to $313 \mathrm{~K}$ and $393 \mathrm{~K}$. The occurrence of peak pressure is at $722.2{ }^{\circ} \mathrm{CA}, 724.8{ }^{\circ} \mathrm{CA}$ and 727.9 ${ }^{\circ} \mathrm{CA}$ at fuel injection timing of $6{ }^{\circ} \mathrm{CA}$ bTDC, $13{ }^{\circ} \mathrm{CA}$ bTDC and 20 ${ }^{\circ} \mathrm{CA}$ bTDC respectively. The injection timing of $20{ }^{\circ} \mathrm{CA}$ bTDC is favorable and fuel temperature of $353 \mathrm{~K}$ are found to be optimum parameters for higher performance in this study. There is a significant rise in peak pressure of $19.7 \%$ by injection advance from $6{ }^{\circ} \mathrm{CA}$ bTDC to $20{ }^{\circ} \mathrm{CA}$ bTDC at fuel temperature of $393 \mathrm{~K}$. The cylinder averaged temperature are plotted in Fig. 9. The cylinder peak temperature is increased more significantly at $6{ }^{\circ} \mathrm{CA}$ bTDC when the fuel temperature is varied from $313 \mathrm{~K}$ to $393 \mathrm{~K}$ as compared to other injection timings. Higher ignition delay and higher evaporation rates of fuel affects the combustion process relatively. Cylinder temperature increases nearly by $200 \mathrm{~K}$ as compared from $6{ }^{\circ} \mathrm{CA}$ bTDC and $20^{\circ} \mathrm{CA}$ bTDC at a fuel temperature of $313 \mathrm{~K}$. However, increase in cylinder temperature beyond the fuel temperature of $353 \mathrm{~K}$ seems insignificant at all injection timings. This is due to evaporation of fuel and ability to mix with air for premixed combustion. The contours of cylinder temperature are obtained at $1 \mathrm{~mm}$ below the cylinder head and plotted for all fuel injection temperatures in Fig. 10.

Tables 4 and 5 list the ignition delay at various swirl ratio of fuel injection temperature of $313 \mathrm{~K}$ and different injection timing of different injection temperatures respectively. As swirl ratio, the turbulence in the cylinder is enhanced and thereby the physical delay is decreased. This helps the air-fuel mixture to burn in premixed mode of combustion. It is also understood that advancement of injection timing leads to longer ignition delay due to the insufficient cylinder pressure when fuel injection temperature is $313 \mathrm{~K}$. For fuel injection temperatures of $353 \mathrm{~K}$ and $393 \mathrm{~K}$, the droplet is partially vaporized and hence the duration of evaporation and mixing with surrounding air is reduced. This results in shorter ignition delay at higher fuel injection temperatures. It can be observed that temperature inside the cylinder rises at certain regions when fuel temperature is increased. Similarly, temperature contours can be investigated in Fig. 11 and Fig. 12 for injection timing of $13{ }^{\circ} \mathrm{CA}$ bTDC and $20{ }^{\circ} \mathrm{CA}$ bTDC 
respectively. The increase in cylinder temperature is clearly evident as fuel injection temperature is raised from $313 \mathrm{~K}$ to $353 \mathrm{~K}$. At further increase i.e from $353 \mathrm{~K}$ to $393 \mathrm{~K}$, a slight increase in temperature can be noticed. This is already explored in Fig. 9 and explained before.

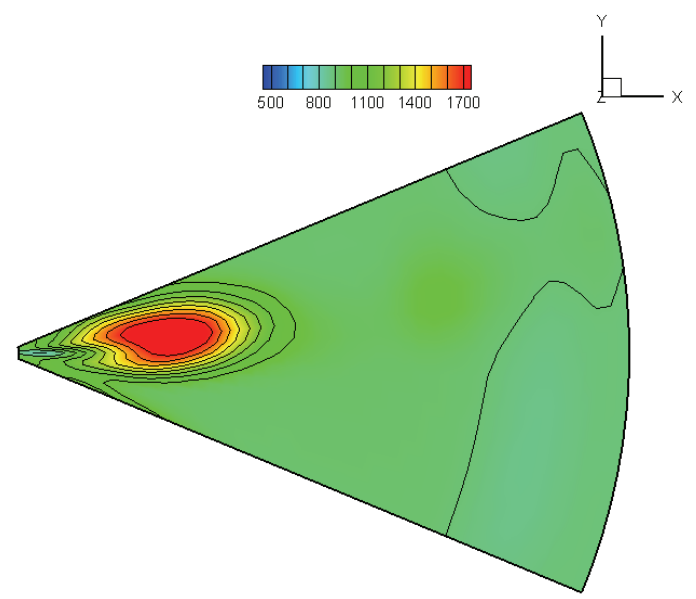

(a) $313 \mathrm{~K}$

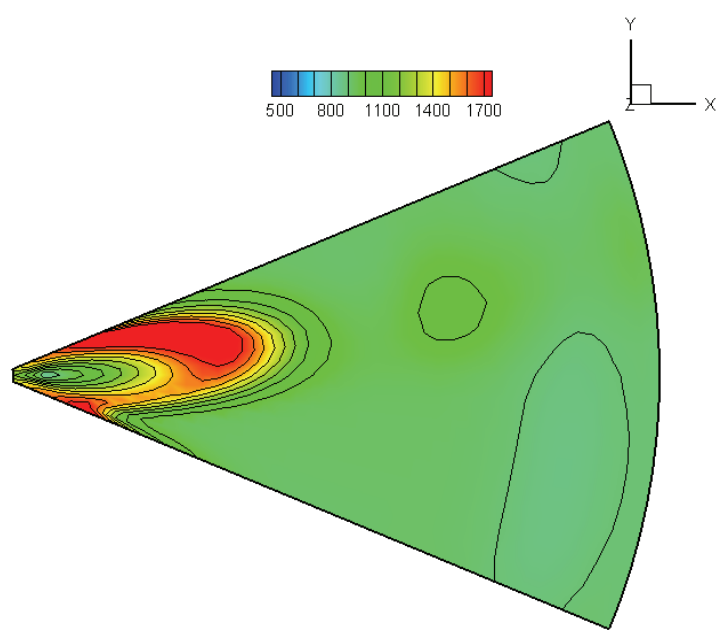

(b) $353 \mathrm{~K}$

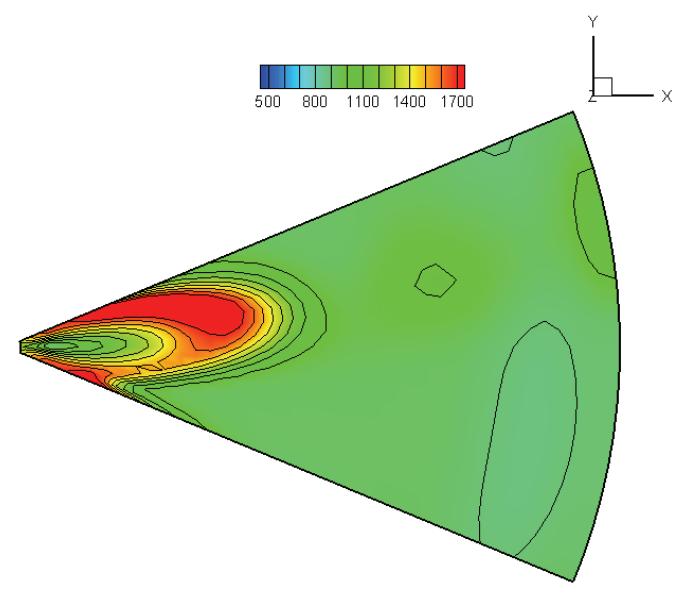

(c) $393 \mathrm{~K}$

Fig. 10 Temperature contours at TDC and injection timing of 714 ${ }^{\circ} \mathrm{CA}$ and fuel injection temperature
Table 5 Delay period for different injection timings and different fuel injection temperatures

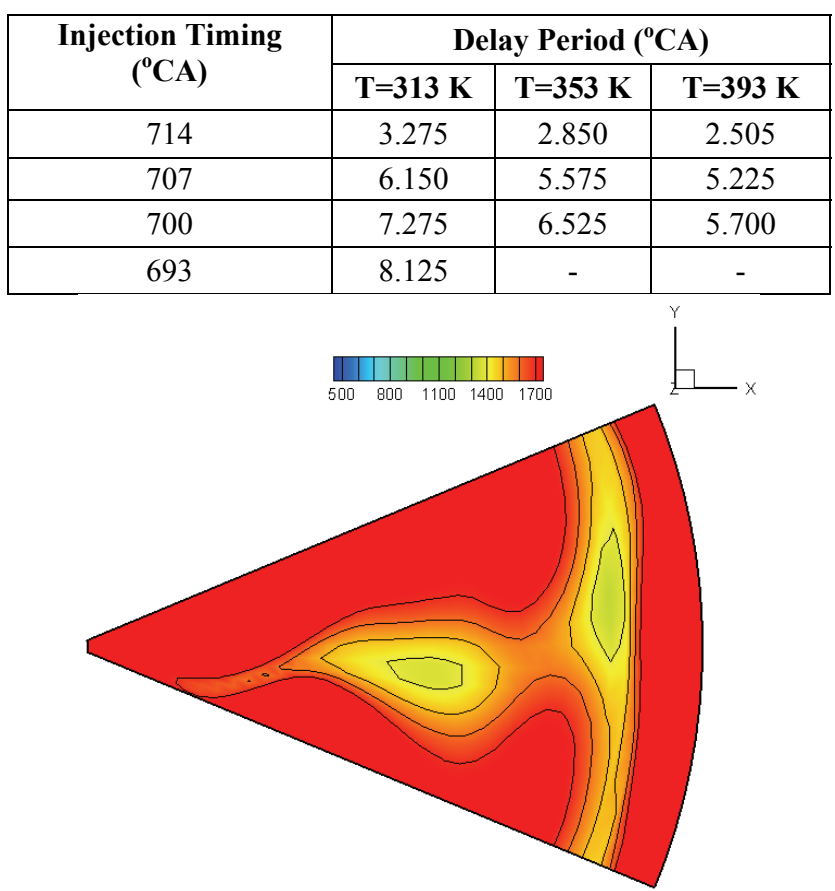

(a) $313 \mathrm{~K}$

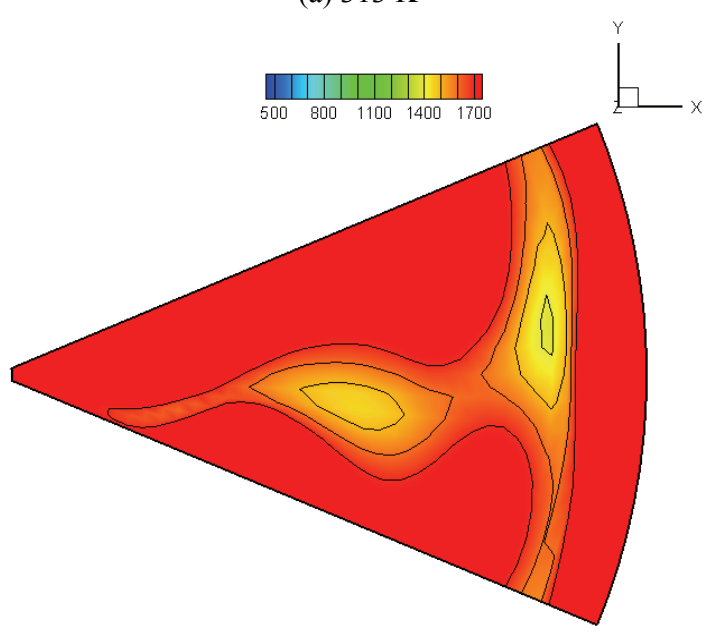

(b) $353 \mathrm{~K}$

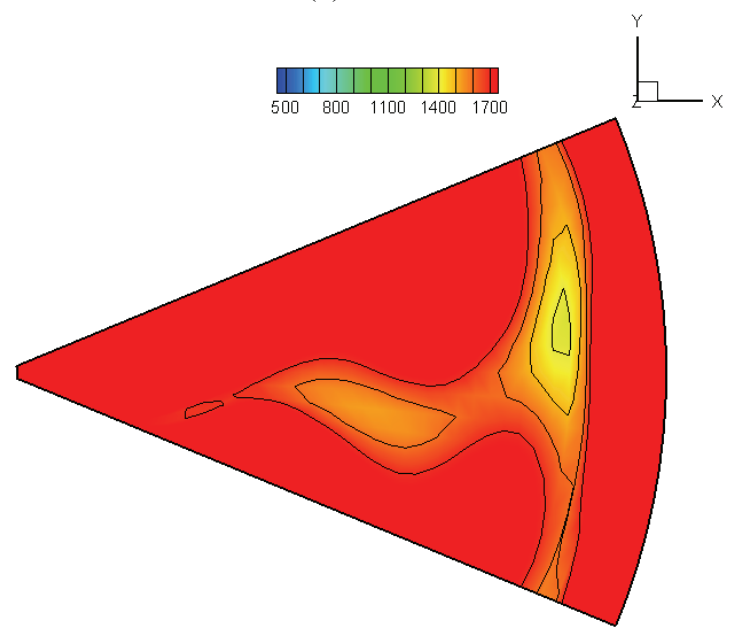

(c) $393 \mathrm{~K}$

Fig. 11 Temperature contours at TDC and injection timing of $707^{\circ} \mathrm{CA}$ and fuel injection temperature 


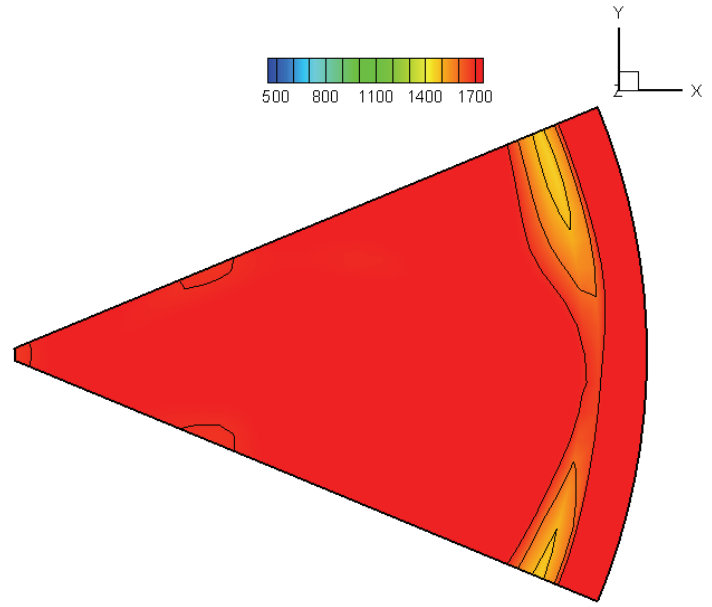

(a) $313 \mathrm{~K}$

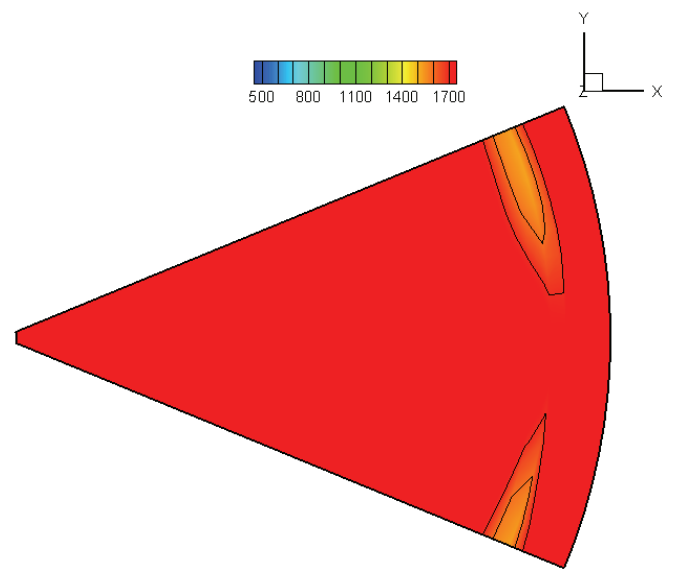

(b) $353 \mathrm{~K}$

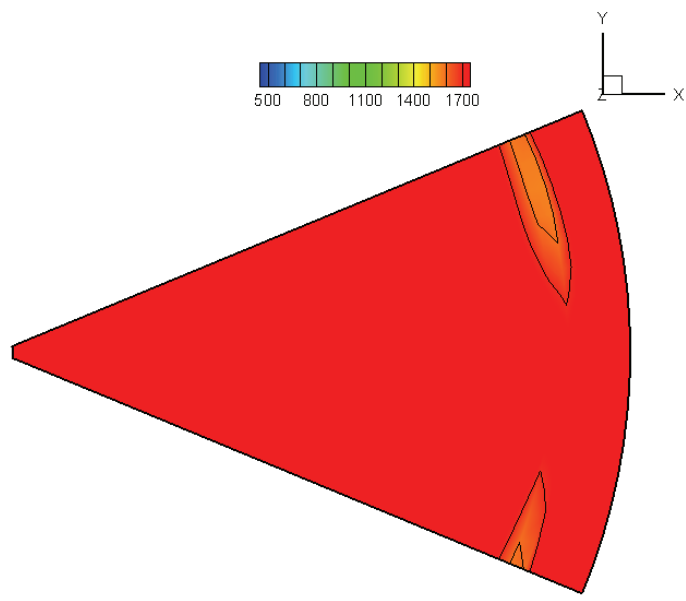

(c) $393 \mathrm{~K}$

Fig. 12 Temperature contours at TDC and injection timing of $700^{\circ} \mathrm{CA}$ and fuel injection temperature

The heat release rate for different fuel temperatures are plotted in Fig. 13. The area under the curve for injection timing of $20{ }^{\circ} \mathrm{CA}$ bTDC is higher as compared to the other two cases for fuel temperature of $313 \mathrm{~K}$. Eventhough the temperature of fuel is increased from $313 \mathrm{~K}$ to $393 \mathrm{~K}$, the rise in heat release is very little for injection timing of $700{ }^{\circ} \mathrm{CA}$. This is already explained from the cylinder peak pressure and temperature as the change is not much significant. At $13{ }^{\circ} \mathrm{CA}$ bTDC, the rise in heat release rate of nearly 3 $\mathrm{J} / \mathrm{deg}$ from fuel temperature of $313 \mathrm{~K}$ to $393 \mathrm{~K}$. The same can be noticed at $6{ }^{\circ} \mathrm{CA}$ bTDC with a significant change of $5 \mathrm{~J} / \mathrm{deg}$. The highest heat release is obtained at $20{ }^{\circ} \mathrm{CA}$ bTDC and $393 \mathrm{~K}$ fuel temperature, promoting premixed combustion during the rising curves for heat release rate for all the cases. However, the curve is steep at 20 ${ }^{\circ} \mathrm{CA}$ bTDC, indicating the sudden premixed combustion as the ignition delay is higher. Once the peak is reached, diffusion combustion follows the falling side of heat release curve. It is also observed that diffusion combustion is longer and premixed combustion is shorter at $20{ }^{\circ} \mathrm{CA}$ bTDC. As the fuel temperature is increased, only the peaks go up but the duration of premixed and diffusion combustion remains almost same for all injection timings. From $6{ }^{\circ} \mathrm{CA}$ bTDC, there is an increase of $13.5 \%$ and $32.6 \%$ as compared at $13{ }^{\circ} \mathrm{CA}$ bTDC and $20{ }^{\circ} \mathrm{CA}$ bTDC respectively. As fuel temperature is varied, increase of $11.7 \%$ and $5.2 \%$ is noticed at 6 ${ }^{\circ} \mathrm{CA}$ bTDC and $13{ }^{\circ} \mathrm{CA}$ bTDC respectively.

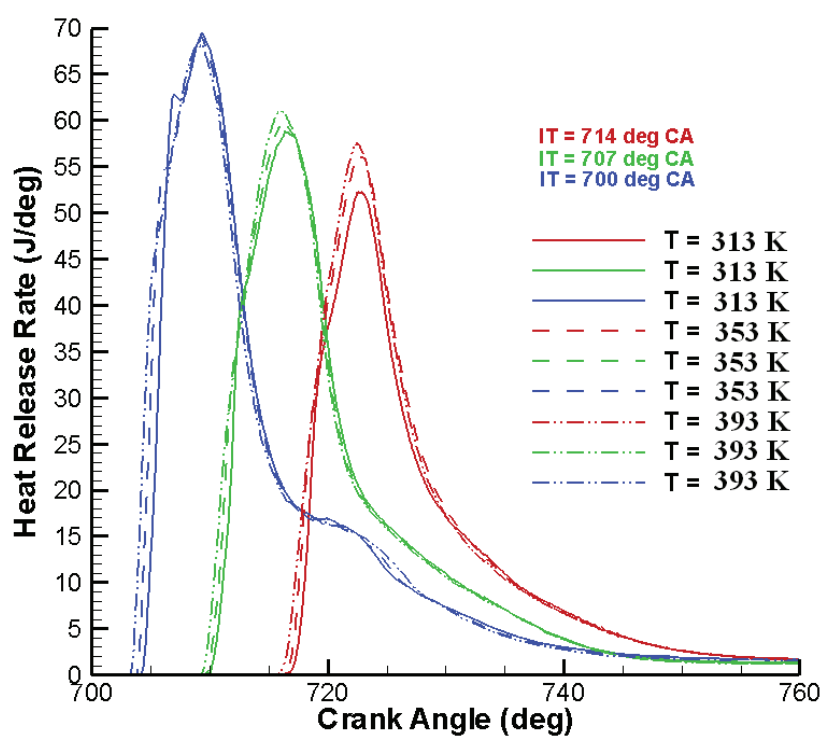

Fig. 13 Variation of heat release rate with crank angle for different injection timing and different fuel injection temperatures

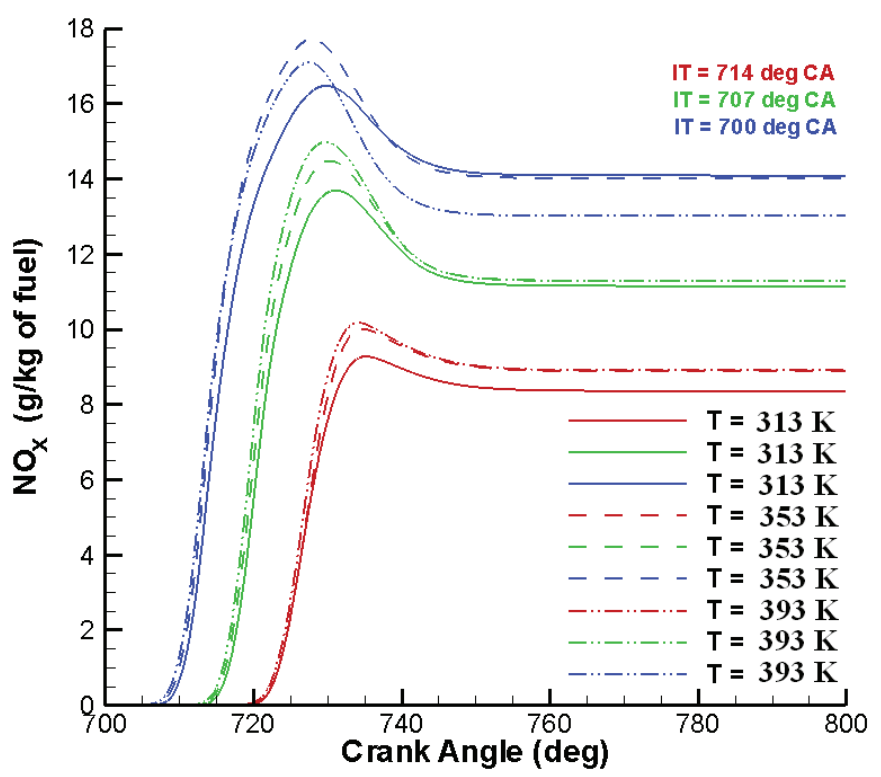

Fig. 14 Variation of $\mathrm{NO}_{\mathrm{X}}$ with crank angle for different injection timing and different fuel injection temperatures

The nitrogen oxides emissions are plotted in Fig. 14. As the cylinder temperature increases, $\mathrm{NO}_{\mathrm{x}}$ levels increase. As the fuel temperature is increased, the nitrogen oxides exhibit higher peak levels. However, the change in peak emissions is significant as the injection timing is advanced. Again a slight increase in emission 
levels is noticed due to higher fuel temperature at $393 \mathrm{~K}$. With respect to the injection timing of $6^{\circ} \mathrm{CA}$ bTDC, an increase of $50 \%$ and $75 \%$ emissions in peak levels at corresponding peak temperatures are observed at $13{ }^{\circ} \mathrm{CA}$ bTDC and $20{ }^{\circ} \mathrm{CA}$ bTDC respectively at fuel injection temperature of $393 \mathrm{~K}$. The soot levels decrease with injection timing and fuel injection temperature as observed in Fig. 15. The soot levels fall from $0.6 \mathrm{~g} / \mathrm{kg}$ of fuel to nearly $0.4 \mathrm{~g} / \mathrm{kg}$ of fuel between an injection timing of $6{ }^{\circ} \mathrm{CA}$ bTDC and $13{ }^{\circ} \mathrm{CA}$ bTDC. Similar decrease in soot emissions is also noticed from the injection timing of $13{ }^{\circ} \mathrm{CA}$ bTDC to $20{ }^{\circ} \mathrm{CA}$ bTDC. During the late burning in the expansion stroke, the soot level reduction of nearly $33.3 \%$ at an injection timing of $6 \mathrm{deg}$ bTDC as fuel injection temperature is increased. Similar reductions in soot emissions are observed in the late burning period. The reduction percentages are $25 \%$ and $12.5 \%$ at injection timings of $13{ }^{\circ} \mathrm{CA}$ bTDC and $20{ }^{\circ} \mathrm{CA}$ bTDC respectively. Although the decrease in soot emissions is pronounced at $20{ }^{\circ} \mathrm{CA}$ bTDC, there is a significant reduction of soot at $6{ }^{\circ} \mathrm{CA}$ bTDC as fuel temperature is increased.

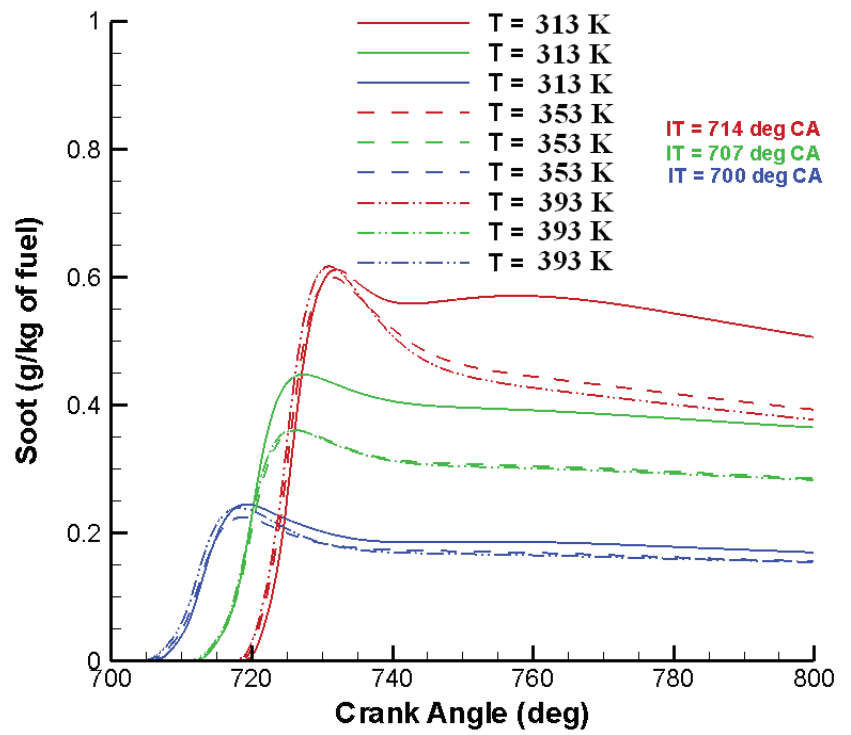

Fig. 15 Variation of soot with crank angle for different injection timing and different fuel injection temperatures

\section{DROPLET PARAMETERS}

The spray processes involved in the study consists of 5 million droplet parcels. Once the injection is started, the fuel is sprayed into the quiescent combustion chamber. Depending on the cylinder pressure, the fuel droplets get atomized. Atomization of fine spray is achieved at lower cylinder pressure as spray penetration is increased. This enables the droplet to overcome the surface tension forces from reformulation. The higher swirl ratio gives an opportunity for the fuel droplet to undergo deformation on the surface and also splitting into ligaments. The aerodynamic drag forces between droplet and surrounding air helps to undergo continuous shear and split until a stage is reached when no further breakup occurs.

The evaporation of drops in a spray occurs due to simultaneous heat and mass transfer processes. Heat is transferred to droplet for evaporation by conduction and convection due to swirl motion. The recirculating gases in the re-entrant chamber help to promote convection heat transfer. If the fuel is completely vaporized, the premixed combustion will result. Otherwise diffusion mode of combustion happens. It is observed from Fig. 16 that droplet mass is higher at an injection timing of $6{ }^{\circ} \mathrm{CA}$ bTDC as compared to other injection timings. This is due to shorter ignition delay in this case. It is further noticed that droplet mass decreases as fuel injection temperature is increased. This is due to evaporation of fuel from the surface of the droplet. There is a predominant decrease in droplet mass at a fuel injection timing of $353 \mathrm{~K}$ and injection timing of 20

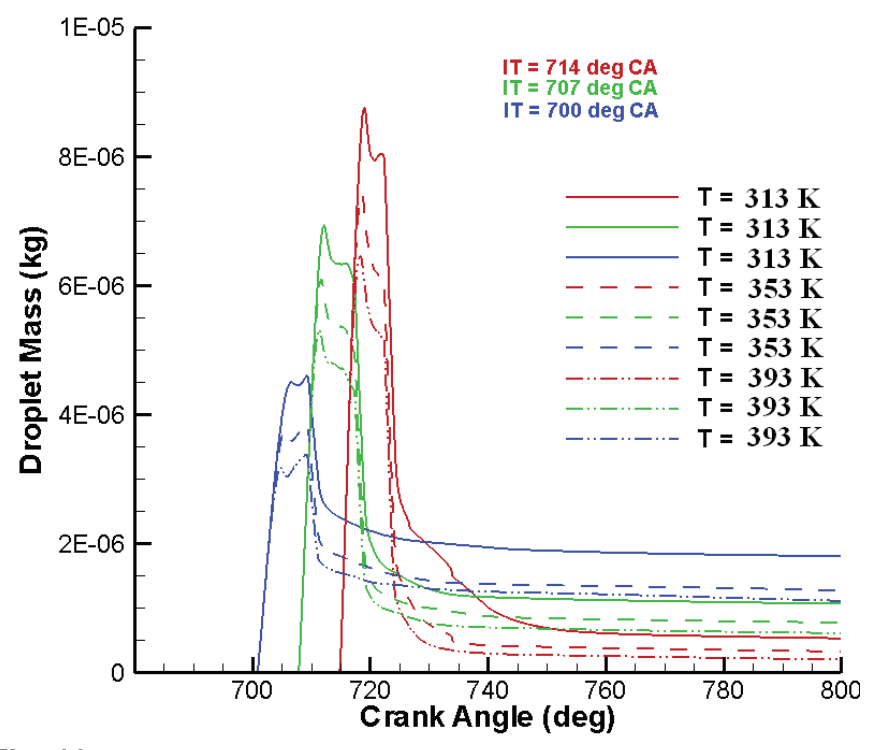

Fig. 16 Variation of droplet mass with crank angle for different injection timing and different fuel injection temperatures

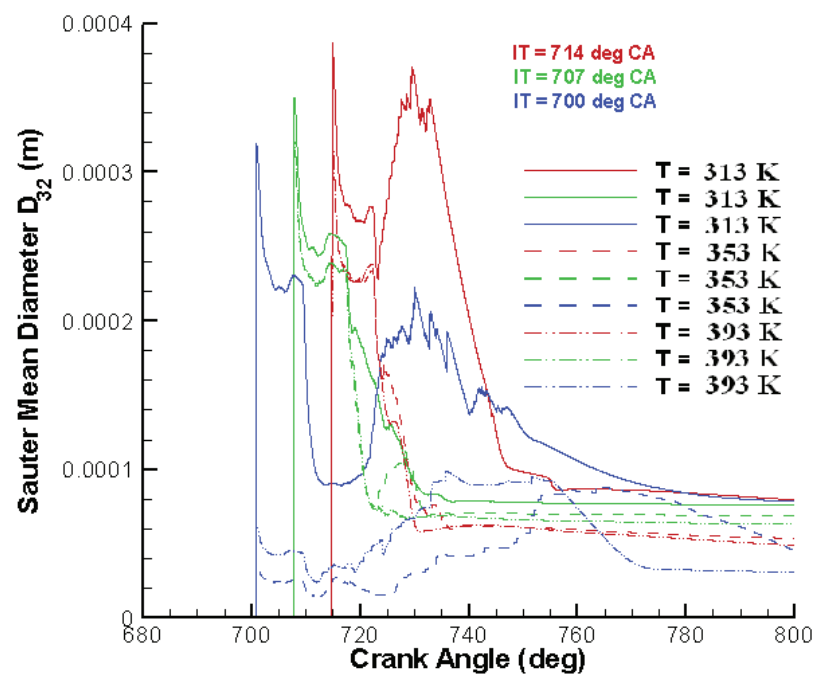

Fig. 17 Variation of droplet SMD with crank angle for different injection timing and different fuel injection temperatures

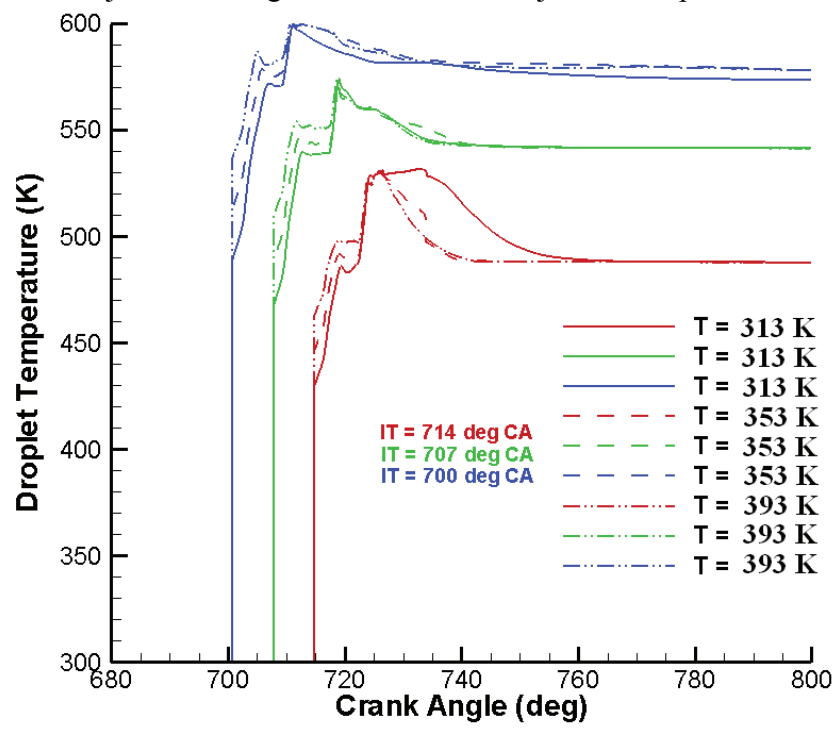

Fig. 18 Variation of droplet temperature with crank angle for different injection timing and different fuel injection temperatures 


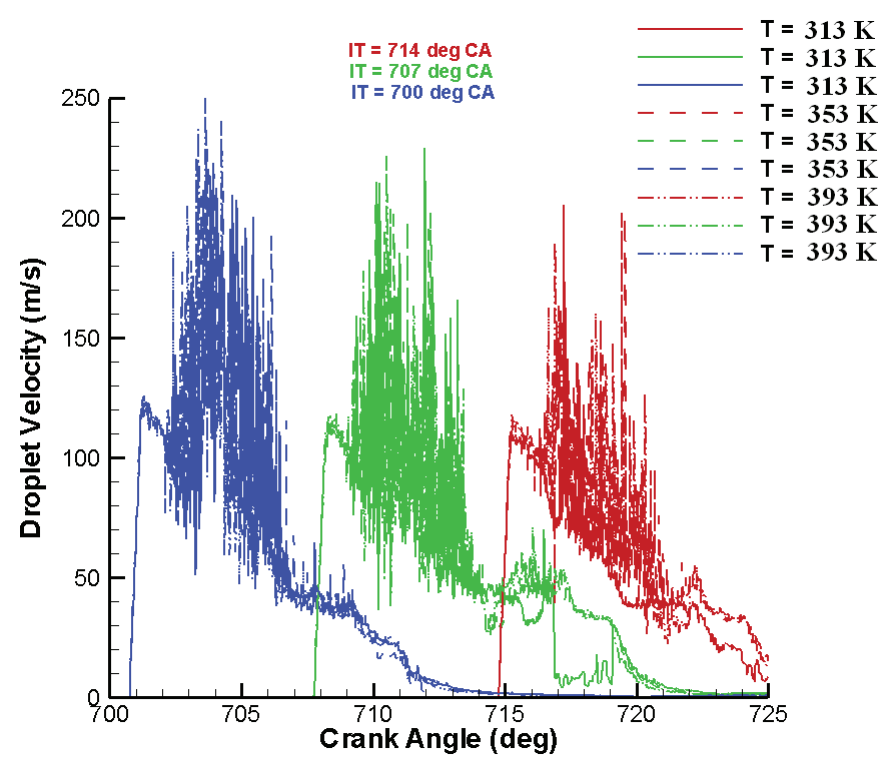

Fig. 19 Variation of droplet velocity with crank angle for different injection timing and different fuel injection temperatures

${ }^{\circ} \mathrm{CA}$ bTDC. A significant droplet size reduction of $89 \%$ is achieved from heating the fuel from $313 \mathrm{~K}$ to $353 \mathrm{~K}$ and advancing the injection timing from $6{ }^{\circ} \mathrm{CA}$ bTDC to $20{ }^{\circ} \mathrm{CA}$ bTDC. Ignition delay period and fuel injection temperature are crucial factors found from this study. The droplet SMD also follows the same as of droplet mass. The distribution of droplet SMD with crank angle is plotted in Fig. 17. The droplet SMD decreases with increase in fuel injection temperature and advancement of injection timing. The droplet mass increases initially due to coalescence with the other droplets. The same phenomena is observed with droplet SMD as second peak is observed at $730{ }^{\circ} \mathrm{CA}$. The coalescence depends on the distribution of droplets, spray cone angle and the ignition delay period.

The droplet temperatures for all cases are plotted in Fig. 18. It is observed that increase in fuel injection temperature seems appreciable effect in the beginning of spray process. There is a marginal increase in droplet temperature for the remaining time period. The droplet velocities are shown in Fig. 19. The droplet velocity increases for higher fuel injection temperature due to lower droplet mass and constant upstream conditions in the injector. Increase in peak velocity from $200 \mathrm{~m} / \mathrm{s}$ to $250 \mathrm{~m} / \mathrm{s}$ occurs for the fuel injection temperature of $393 \mathrm{~K}$ when injection timing is advanced from $6{ }^{\circ} \mathrm{CA}$ bTDC to 20 ${ }^{\circ} \mathrm{CA}$ bTDC. The variation in velocity profile may be due to turbulent flow field at higher swirl ratio that is favorable for evaporation, mixing, combustion processes in the re-entrant bowl volume.

\section{CONCLUSIONS}

Numerical models are represented for various physical processes during the combustion and pollution formation in the present study. The optimal steps for discretizing the space and time domain are found out for carrying out simulation of combustion. The CFD result is validated with the literature and found that maximum of deviation of pressure between CFD and experiments is within $0.2 \%$. The studies are further continued to increase the in-cylinder peak pressure by modifying the combustion chamber bowl for better swirl inside. The increase in swirl ratio brings a rise in pressure of 6.8 bar amounting to $9.3 \%$. The studies on elevated fuel temperature are conducted at fuel injection temperature of $313 \mathrm{~K}, 353 \mathrm{~K}$ and $393 \mathrm{~K}$. The simulations are performed at injection timings of $6{ }^{\circ} \mathrm{CA}$ bTDC, $13{ }^{\circ} \mathrm{CA}$ bTDC and $20{ }^{\circ} \mathrm{CA}$ bTDC. The results are inferred and the following conclusions are drawn.
1. When the injection timing is advanced from $6{ }^{\circ} \mathrm{CA}$ bTDC to $20{ }^{\circ} \mathrm{CA}$ bTDC and injection temperature of $313 \mathrm{~K}$, the peak in-cylinder pressure increases by 11.1 bar thereby resulting in better combustion. At an elevated fuel temperature of 353 $\mathrm{K}$, the advancement of injection timing from $6{ }^{\circ} \mathrm{CA}$ bTDC to $20^{\circ} \mathrm{CA}$ bTDC leads to an increase in peak pressure from 80.1 bar to 96.1 bar. Hence there is another contribution of 5.2 bar in peak cylinder pressure, obtained by heating the fuel to $353 \mathrm{~K}$ from $313 \mathrm{~K}$. The fuel can be safely heated to $353 \mathrm{~K}$ which is below the flash point of fuel $(356 \mathrm{~K})$.

2. Heat release rate increases by $13.5 \%$ and $32.6 \%$ for the injection timing $13{ }^{\circ} \mathrm{CA}$ bTDC and $20{ }^{\circ} \mathrm{CA}$ bTDC respectively as compared to the injection timing of $6{ }^{\circ} \mathrm{CA}$ bTDC. As fuel temperature is varied, increase of $11.7 \%$ and $5.2 \%$ is noticed at $6{ }^{\circ} \mathrm{CA}$ bTDC and $13{ }^{\circ} \mathrm{CA}$ bTDC respectively.

3. In-cylinder temperature rises significantly when injection timing is advanced. There is only a marginal increase in temperature observed at some locations when the fuel temperature is varied. This is noticed at all the injection timings considered in this study.

4. At a fuel injection temperature of $393 \mathrm{~K}, \mathrm{NO}_{\mathrm{x}}$ emissions increases to $50 \%$ and $75 \%$ in peak levels for an injection timing of $13{ }^{\circ} \mathrm{CA}$ bTDC and $20{ }^{\circ} \mathrm{CA}$ bTDC respectively as compared to $6{ }^{\circ} \mathrm{CA}$ bTDC. At low fuel injection temperature and retarded fuel injection timing, NOx level is reduced.

5. Due to the rise in injection fuel temperature, soot formation gets lowered significantly to $33.3 \%, 25 \%$ and $12.5 \%$ for injection timing of $6{ }^{\circ} \mathrm{CA}$ bTDC. Soot levels decreases significantly at an injection timing of $6{ }^{\circ} \mathrm{CA}$ bTDC when fuel injection temperature is increased from $313 \mathrm{~K}$ to $353 \mathrm{~K}$.

6. A significant droplet size reduction of $89 \%$ is achieved from heating the fuel from $313 \mathrm{~K}$ to $353 \mathrm{~K}$ and advancing the injection timing from $6{ }^{\circ} \mathrm{CA}$ bTDC to $20{ }^{\circ} \mathrm{CA}$ bTDC. The droplet mass increases initially and droplet SMD shows double peaks due to coalescence with the other droplets. The coalescence depends on the distribution of droplets, spray cone angle and the ignition delay period.

\section{NOMENCLATURE}

\section{Abbreviations}

\begin{tabular}{ll} 
bTDC & before Top Dead Centre \\
BDC & Bottom Dead Centre \\
CA & Crank Angle \\
CAD & Computer Aided Design \\
CFD & Computational Fluid Dynamics \\
CO & Carbon monoxide \\
D & \multicolumn{1}{c}{ Diameter } \\
Deg & degrees \\
EGR & Exhaust Gas Recirculation \\
HC & Hydrocarbons \\
IT & Injection timing \\
J & Joule \\
K & Turbulent kinetic energy \\
NO & Oxides of nitrogen \\
Oh & Ohnesorge number \\
Re & Reynolds number \\
SR & Swirl ratio \\
SMD & Sauter Mean Diameter \\
T & Temperature \\
TDC & Top Dead Centre
\end{tabular}


u Velocity

We Weber number

Greek symbols

$\varepsilon \quad$ Turbulent eddy dissipation rate

$\mu \quad$ Dynamic viscosity

$\rho \quad$ Density

$\sigma \quad$ Surface tension

$\tau \quad$ Life time

Suffixes

B breakup

D droplet

G gas phase (Eulerian)

Rel relative

\section{REFERENCES}

O'Rourke, P.J., 1981, Collective Drop Effects on Vaporising Liquid Sprays, PhD Thesis, University of Princeton.

Aleiferis P.G., and van Romunde Z.R., 2012, "An analysis of Spray Development with iso-octane, n-pentane, Gasoline, Ethanol and nButanol from a Multi-Hole Injector under Hot Fuel Conditions," Fuel, $105,143-168$.

http://dx.doi.org/10.1016/i.fuel.2012.07.044.

Angelberger C., Poinsot T., Delhay B., 1997, "Improving Near-Wall Combustion and Wall Heat Transfer Modeling in SI Engine Computations," SAE Technical Paper Series 972881.

Bai, C., and Gosman, A.D., 1996, "Mathematical Modeling of Wall Films formed by Impinging Sprays," SAE Technical Paper Series 960626.

Bari, S., Lim, T.H., and Yu, C.W., 2002, "Effects of Preheating of Crude Palm Oil (CPO) on Injection System, Performance and Emission of a Diesel Engine," Renewable Energy, 27, 339-351. http://dx.doi.org/10.1016/S0960-1481(02)00010-1

Chen, G., 2008, "Study of Fuel Temperature Effects on Fuel Injection, Combustion, and Emissions of Direct-Injection Diesel Engines," J. Eng. Gas Turbines Power, Transactions of ASME, 131(2), 022802.

http://dx.doi.org/10.1115/1.3019006

Chhetri, A. B., and Watts, K.C., 2012, "Surface Tensions of Petrodiesel, Canola, Jatropha and Soapnut Biodiesel Fuels at Elevated Temperatures and Pressures," Fuel, 104, 704-710.

http://dx.doi.org/10.1016/i.fuel.2012.05.006.

Colin O., and Benkenida A., 2004, "The 3-Zone Extended Coherent Flame Model (ECFM3Z) for Computing Premixed/Diffusion Combustion," Oil \& Gas Science and Technology - Rev. IFP, 59, 593-609.

De Soete G.G., 1975, "Overall Reaction Rates of $\mathrm{NO}$ and $\mathrm{N}_{2}$ Formation from Fuel Nitrogen," 15th Symp. (Int.) on Combustion, The Combustion Institute 1093-1102.

El Tahry, S.H., 1983, "k- $\varepsilon$ Equation for Compressible Reciprocating Engine Flows," AIAA, J. Energy, 7, 345-353.
Forson, F.K., Oduro, E.K., and Hammond-Donkoh, E., 2004, "Performance of Jatropha Oil Blends in a Diesel Engine," Renewable Energy, 29, 1135-1145.

http://dx.doi.org/10.1016/j.renene.2003.11.002

Hand, G., Missaghi, M., Pourkashanian, M., and Williams, A., 1989, "Experimental Studies and Computer Modelling of Nitrogen Oxides in a Cylindrical Natural Gas Fired Furnace," 9th Members Conf., International Flame Research Foundation, Noordwijkerhout, The Netherlands.

Heywood J. B., 1988, Internal Combustion Engine Fundamentals, McGraw-Hill, New York, 491-566.

Hossainpour, S., and Binesh, A.R., 2009, "Investigation of Fuel Spray Atomization in a DI Heavy-Duty Diesel Engine and Comparison of Various Spray Breakup Models," Fuel, 88, 799-805. http://dx.doi.org/10.1016/j.fuel.2008.10.036

Huh K.Y., and Gosman A.D., 1991, "A Phenomenological model of Diesel spray atomization," Proc. Int. Conf. on Multiphase Flows (ICMF '91), Tsukuba, 24-27 September 1991.

Mauss, F., Netzell, K., and Lehtiniemi, H., 2006, "Aspects of Modeling Soot Formation in Turbulent Diffusion Flames," Combust. Sci. and Tech. 178, 1871 .

http://dx.doi.org/10.1080/00102200600790888

Myong, K.J., Suzuki, H., Senda, J., and Fujimoto, H., 2006, "Evaporation Characteristics of Multi-Component Fuel," Fuel, 85, 2632-2639.

http://dx.doi.org/10.1016/j.fuel.2006.04.020

Nwafor, O.M.I., 2004, "Emission Characteristics of Diesel Engine Running on Vegetable Oil with Elevated Fuel Inlet Temperature," Biomass and Bioenergy, 27, 507 - 511

http://dx.doi.org/10.1016/j.biombioe.2004.02.004

Prasad, B.V.V.S.U., Sharma, C.S., Anand, T.N.C., and Ravikrishna, R.V.. 2011, "High Swirl-Inducing Piston Bowls in Small Diesel Engines for Emission Reduction," Applied Energy, 88, 2355-2367. http://dx.doi.org/10.1016/j.apenergy.2010.12.068

Reitz R.D., and Diwakar R., 1986, "Effect of drop breakup on fuel sprays," SAE Technical Paper Series, 860469.

Rohsenow, W.M., 1952, “A Method of Correlating Heat Transfer Data for Surface Boiling Liquids," Transactions of the ASME, 74, 969.

Senthil Kumar, M., Kerihuel, A., Bellettre, J., and Tazerout, M., 2005, "Experimental Investigations on the Use of Preheated Animal Fat as Fuel in a Compression Ignition Engine," Renewable Energy, 30, 1443-1456.

http://dx.doi.org/10.1016/j.renene.2004.11.003

STAR Methodology For Internal Combustion Engine Applications, CD-adapco version 4.16, (2010).

Yilmaz, N., 2012, "Performance and Emission Characteristics of a Diesel Engine Fuelled with Biodiesel- Ethanol and BiodieselMethanol Blends at Elevated Air Temperatures," Fuel, 94, 440-443. http://dx.doi.org/10.1016/j.fuel.2011.11.015 